Check for updates

Cite this: Chem. Commun., 2021, 57,5814

Received 23rd February 2021, Accepted 4th May 2021

DOI: $10.1039 / \mathrm{d} 1 \mathrm{cc} 01029 \mathrm{~h}$

rsc.li/chemcomm

\section{Targeted pH switched europium complexes monitoring receptor internalisation in living cells $\dagger$}

\author{
Jack D. Fradgley, ${ }^{a}$ Matthieu Starck, (D) ${ }^{a}$ Michel Laget, ${ }^{b}$ Emmanuel Bourrier, ${ }^{b}$ \\ Elodie Dupuis, ${ }^{\mathrm{b}}$ Laurent Lamarque, ${ }^{\mathrm{b}}$ Eric Trinquet, ${ }^{\mathrm{b}}$ Jurriaan M. Zwier ${ }^{\mathrm{b}}$ and \\ David Parker (D) *a
}

We report the design and evaluation of $\mathrm{pH}$ responsive luminescent europium(III) probes that allow conjugation to targeting vectors to monitor receptor internalisation in cells. The approach adopted here can be used to tag proteins selectively and to monitor uptake into more acidic organelles, thereby enhancing the performance of time-resolved internalisation assays that require $\mathrm{pH}$ monitoring in real time.
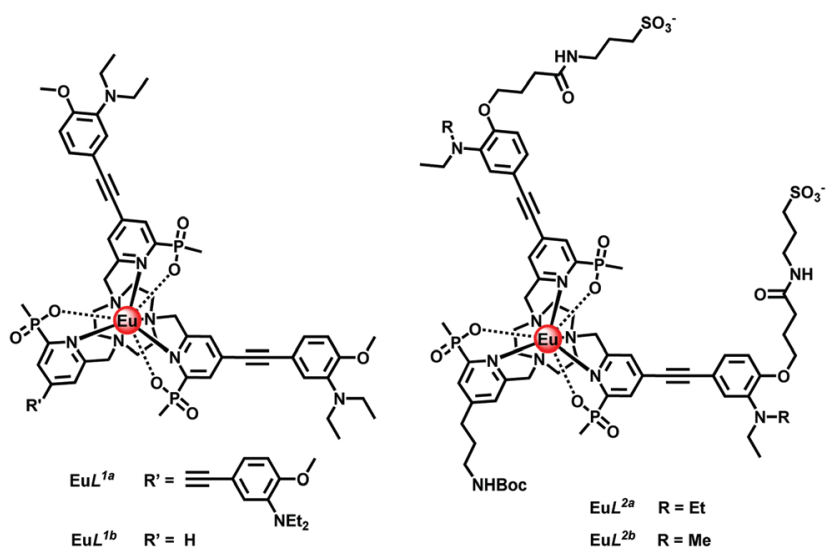

During the ageing process of endosomes and phagosomes, the $\mathrm{pH}$ tends to reduce with time and endosomes eventually may evolve into lysosomes. The cytosolic pH of healthy cells is around 7.2, whereas endosomal $\mathrm{pH}$ varies from 6.5 to 5.5 ; in mature lysosomes the $\mathrm{pH}$ is typically around 4.5. Receptor internalisation and endosomal uptake $\mathrm{i}^{1}$ can be monitored provided that the species that is internalised (receptor or substrate) is labelled with a pH sensitive dye, whose emission intensity or lifetime varies significantly with $\mathrm{pH} .^{2-5}$

\footnotetext{
${ }^{a}$ Department of Chemistry, Durham University, South Road, Durham DH1 3LE, UK. E-mail: david.parker@dur.ac.uk

${ }^{b}$ Cisbio Bioassays, BP 84175, 30200 Codolet, France

$\dagger$ Electronic supplementary information (ESI) available: Ligand and complex synthesis; photophysical data and spectra; cell experiments. See DOI: 10.1039/ d1cc01029h
}

Recently, we have identified europium(III) complexes that show a pH dependent change in lifetime of a factor of 3 and an emission intensity pH switching ratio of around two orders of magnitude, using time-gated acquisition methods. ${ }^{6}$ Each of these $\mathrm{Eu}(\mathrm{III})$ complexes is $\mathrm{C}_{3}$ symmetric and contains strongly absorbing alkynyl-aryl chromophores, e.g. EuL ${ }^{1 a}$ with a brightness of $10200 \mathrm{M}^{-1} \mathrm{~cm}^{-1}(332 \mathrm{~nm})$ in acidic conditions. With a conjugated diethylamino group the $\mathrm{p} K_{a}$ value is $6.2(295 \mathrm{~K})$ and falls by one unit as a methyl group replaces one of the ethyl substituents. The absorption spectrum changes with $\mathrm{pH}$ because acidification perturbs the energy of the ligand centred and internal charge transfer transitions that exist in these EuroTracker ${ }^{\mathrm{TM}}$ dyes and related series of complexes. ${ }^{7-12}$

With this background in mind, we set about preparing complexes suitable for use in cellulo that are hydrophilic and appropriately substituted to enable conjugation to targeting vectors. Thus, in $\mathbf{E u} \boldsymbol{L}^{2 a / 2 b}$ (Scheme S2, ESI $\dagger$ ), peripheral sulfonate groups on the two conjugated chromophores were introduced in order to minimise non-specific binding of the complex to proteins. ${ }^{12}$ In addition, the simple pyridine group was functionalised with a primary amino-propyl group ( $N$-Boc protected), in order to permit subsequent site-selective conjugation to different targeting vectors. ${ }^{13}$ The synthesis of the Eu(III) complexes of $\boldsymbol{L}^{1 b}$ and $\boldsymbol{L}^{2 a / 2 b}$ was undertaken in a similar manner, (Scheme 1 and Scheme S2, ESI + ), from mono-Boc-1,4,7-triazacyclononane. The syntheses involved a series of $N$-alkylation and simple deprotection steps, and the final complexes were purified by reverse phase HPLC. Under the strongly acidic conditions of the Boc removal step, protonation of the proximate dialkylamino group inhibits any unwanted acid catalysed alkyne hydration. Reaction of the mesylate $1,{ }^{6}$ with mono-Boc-1,4,7-triazacyclononane gave the carbamate 2, followed by treatment with TFA in $\mathrm{CH}_{2} \mathrm{Cl}_{2}$ to yield the amine 3 . Alkylation with the disubstituted pyridine mesylate $4,{ }^{14}$ afforded the ester $\mathbf{5}$, and basic hydrolysis in aqueous methanol followed by complexation with $\mathrm{EuCl}_{3}$ at $\mathrm{pH} 6$ gave the desired neutral complex, EuL. ${ }^{1 b}$

The absorption spectrum of $\mathbf{E} \mathbf{u} \boldsymbol{L}^{2 b}$ showed a pH dependence associated with reversible protonation of the dialkylamino 

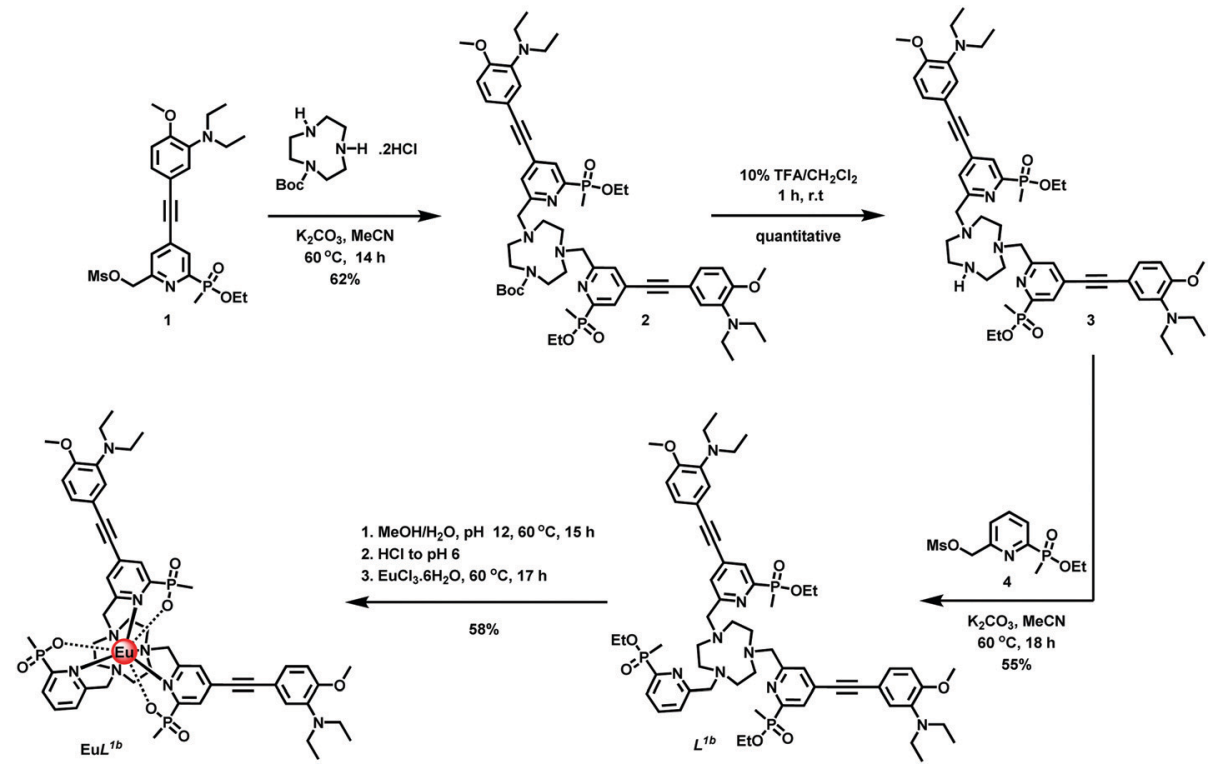

Scheme 1 Synthesis of complex EuL ${ }^{1 b}$

group that was characterised by the appearance of two isosbestic points at 284 and $332 \mathrm{~nm}$, (Fig. 1). Similar behaviour was found with the other two complexes (Fig. S1 and S3-S5, ESI†). In each case, protonation switched on europium luminescence and the emission lifetime and intensity were measured as a function of pH (Fig. 2, Tables 1 and 2). Thus, with $\mathbf{E u L}^{2 a}$ excitation at the isosbestic point led to an increase in lifetime from $0.24(\mathrm{pH} 8)$ to $1.02 \mathrm{~ms}(\mathrm{pH} 4)$ with a 50-fold increase in emission intensity (Fig. S6, ESI†). Monitoring changes in emission lifetime or intensity allowed $\mathrm{p} K_{a}$ values to be estimated. In $0.1 \mathrm{M} \mathrm{NaCl}$ solution, the $N, N$-diethyl complexes had similar values around 6.2, reducing to 5.34 for the $N$-methylethyl analogue, $\mathbf{E u} L^{2 b}$ (Fig. S10-S12, ESI $\dagger$ ). These $\mathrm{p} K_{a}$ values are sensitive to the nature of the medium and reduced slightly in cell lysate solution, highlighting the need to calibrate the $\mathrm{pH}$ dependence in the medium of interest.

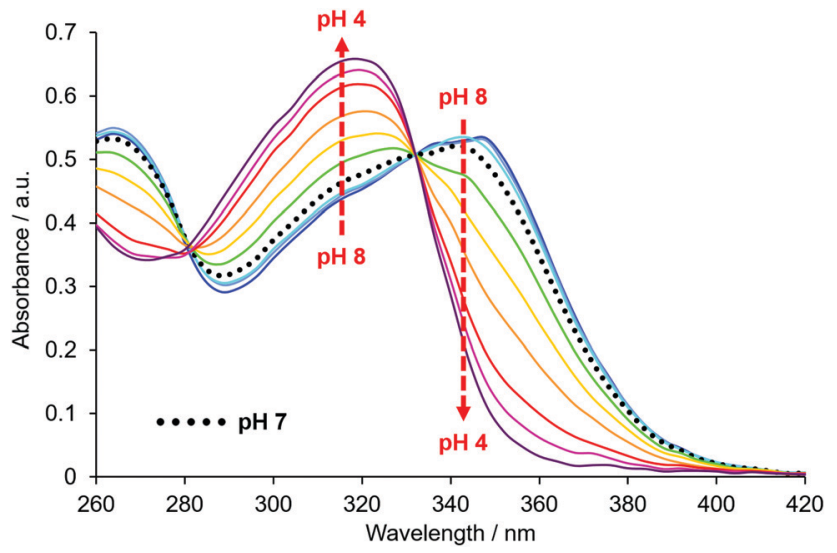

Fig. $1 \mathrm{pH}$ Variation of the absorbance spectrum of EuL ${ }^{2 b}(295 \mathrm{~K}, 0.1 \mathrm{M}$ $\mathrm{NaCl}$, showing isosbestic points at 284 and $332 \mathrm{~nm}$.

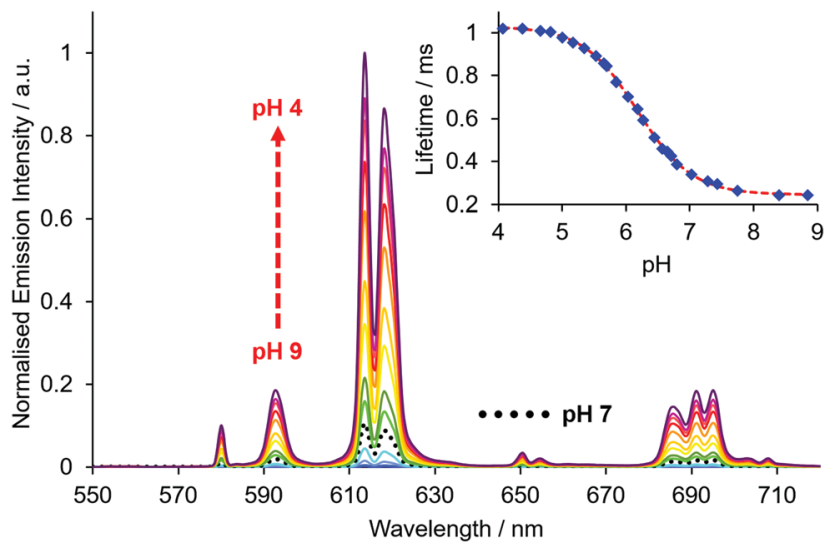

Fig. $2 \mathrm{pH}$ Variation of the europium emission spectrum of EuL ${ }^{2 a}$ $\left(\lambda_{\text {exc }} 332 \mathrm{~nm}, 295 \mathrm{~K}, \mathrm{c}=20 \mu \mathrm{M}, 0.1 \mathrm{M} \mathrm{NaCl}\right)$; the inset shows the variation of the europium emission lifetime with $\mathrm{pH}\left(\lambda_{\mathrm{exc}} 332 \mathrm{~nm}, \lambda_{\mathrm{em}} 613 \mathrm{~nm}\right)$. A p $K_{\mathrm{a}}$ value of 6.18 was estimated by non-linear least squares regression analysis.

Table 1 Summary of $\mathrm{p} K_{\mathrm{a}}$ values determined for Eu(III) complexes. ${ }^{a}$

\begin{tabular}{lll}
\hline Complex & Conditions & $\mathrm{p} K_{a}$ \\
\hline $\mathbf{E u} \boldsymbol{L}^{1 a}$ & $0.1 \mathrm{M} \mathrm{NaCl}$ & $6.21(03)$ \\
& NIH-3T3 cell lysate & $5.92(04)$ \\
$\mathbf{E u} L^{1 b}$ & $0.1 \mathrm{M} \mathrm{NaCl}$ & $6.30(03)$ \\
& NIH-3T3 cell lysate & $6.25(04)$ \\
$\mathbf{E} \boldsymbol{L}^{2 a}$ & $0.1 \mathrm{M} \mathrm{NaCl}$ & $6.18(03)$ \\
& NIH-3T3 cell lysate & $6.00(04)$ \\
$\mathbf{E u} L^{2 b}$ & $0.1 \mathrm{M} \mathrm{NaCl}$ & $5.34(03)$ \\
& NIH-3T3 cell lysate & $5.28(04)$ \\
${ }^{a} \mathrm{p} K_{\mathrm{a}}$ values given are the mean of three replicates, at $295 \mathrm{~K}$.
\end{tabular}

In each case, the increases in quantum yield and brightness (Table 2) following acidification are in accord with a strongly 
Table 2 Photophysical properties of the stated Eu(III) complexes (295 K, $0.1 \mathrm{M} \mathrm{NaCl})$

\begin{tabular}{lllllll}
\hline Complex & $\lambda_{\text {exc }} / \mathrm{nm}$ & $\varepsilon / \mathrm{M}^{-1} \mathrm{~cm}^{-1}$ & $\tau / \mathrm{ms}^{e}$ & $\Phi / \%^{e}$ & $q$ & $B / \mathrm{M}^{-1} \mathrm{~cm}^{-1 f}$ \\
\hline $\mathbf{E u} L^{1 a}$ & 331 & $60000^{a, d}$ & $0.25^{b}$ & $0.1^{b}$ & 0 & $46^{b}$ \\
& & & $0.84^{c}$ & $17^{c}$ & & $10200^{c}$ \\
$\mathbf{E u L} L^{1 b}$ & 328 & $35000^{a}$ & $0.34^{b}$ & $0.2^{a}$ & 0 & $70^{b}$ \\
& & & $1.00^{c}$ & $18^{b}$ & & $6300^{c}$ \\
$\mathbf{E u L} L^{2 a}$ & 332 & $39000^{a}$ & $0.24^{b}$ & $0.3^{a}$ & 0 & $117^{b}$ \\
& & & $1.02^{c}$ & $16^{b}$ & & $6240^{c}$ \\
$\mathbf{E u L} L^{2 b}$ & 332 & $39000^{a}$ & $0.28^{b}$ & $0.01^{a}$ & 0 & $4^{b}$ \\
& & & $1.04^{c}$ & $15^{b}$ & & $5850^{c}$
\end{tabular}

${ }^{a}$ Value at the isosbestic point. ${ }^{b}$ Value at $\mathrm{pH}=8 .{ }^{c}$ Value at $\mathrm{pH}=4$. ${ }^{d}$ Data from Ref. 6. ${ }^{e}$ Errors in lifetime measurements are $\pm 10 \%$ and in quantum yields $\pm 15 \% .{ }^{f}$ Brightness values are given at the stated excitation wavelength.

emissive and longer-lived protonated complex (see the invariance of the form of the excitation spectra with pH: Fig. S4, S7 and S13, ESI $\dagger$ ), wherein the photo-induced electron transfer process that quenches the europium excited state is suppressed. By varying both the delay time and time window for signal acquisition, the 'switch-on' can be increased, as signal from the more emissive complex is favoured. For example, by using a delay time of $1.5 \mathrm{~ms}$ and acquiring signal for one millisecond (1500-2500 $\mu$ s acquisition period), intensity ratios for $\mathrm{pH} 4 / \mathrm{pH} 8$ solutions of around 500 were found (Table 3 and Fig. 3; Fig. S8/9; Table S1, ESI $\dagger$ ), with a progressive diminution in the apparent $\mathrm{p} K_{\mathrm{a}}$ value as the delay time was increased.

In a proof-of-concept study for membrane receptor labelling and trafficking, the benzylguanine (BG) derivative $\mathbf{E u} L,{ }^{2 c}$ was prepared from $\mathbf{E u} \boldsymbol{L}^{2 a}$ using established methodology (Scheme $\mathrm{S} 3, \mathrm{ESI} \dagger)^{12}{ }^{12}$ The BG derivative serves to label the SNAP-tag (ST), a self-labelling suicide enzyme ${ }^{15}$ often used to study G-Protein Coupled Receptors (GPCRs). Previous studies have shown that $\mathrm{Eu}(\mathrm{III})^{12}$ and $\mathrm{Tb}$ (III) derivatives ${ }^{16,17}$ can be used to label SNAP tagged receptors. Using the non-pH sensitive Lumi4-Tb complex, ${ }^{18}$ the Tag-lite technology ${ }^{\mathbb{R}}$ emerged and Lumi4-Tb labelled GPCR can be used to signal receptor internalisation. Therefore, such a model is well suited to test the behaviour of these new europium $\mathrm{pH}$ responsive probes.

The glucagon-like peptide- 1 receptor (GLP-1R) is a receptor targeted for anti-diabetic drugs since it is involved in the metabolic pathway for insulin production. Tools to study its agonist-induced internalisation ${ }^{19,20}$ are therefore in high demand. After labelling a HEK-293 cell line that stably expresses GLP-1R-ST with $200 \mathrm{nM}$ of $\mathbf{E u}^{2 c}$ at $\mathrm{pH}$ 7.4, the Eu time-gated luminescence was observed (Fig. 4A: $620 \mathrm{~nm}, \Delta J=2$ band, $\mathrm{pH} 4.5$, acetate buffer; ESI $\dagger$ ). Since labelling to non-

Table 3 Ratios of emission intensities (/ rel $_{\text {r }}$ 'switch-on' factors) for EuL ${ }^{1 b}$ / $\mathrm{EuL}^{2 a}$ for differing time gate periods, showing the effect on the apparent $\mathrm{p} K_{\mathrm{a}}$ values $\left(295 \mathrm{~K}, \mathrm{c}=20 \mu \mathrm{M}, 0.1 \mathrm{M} \mathrm{NaCl}\right.$; buffers, $\mathrm{NH}_{4} \mathrm{OAc}(0.1 \mathrm{M}, \mathrm{pH}$ 4), $\left.\mathrm{NH}_{4} \mathrm{HCO}_{3}(0.1 \mathrm{M}, \mathrm{pH} 8)\right)$

\begin{tabular}{llll}
\hline & $60-460 \mu \mathrm{s}$ & $1000-2000 \mu \mathrm{s}$ & $1500-2500 \mu \mathrm{s}$ \\
\hline$I_{\text {rel }}: \mathrm{pH} 4 / \mathrm{pH} 8$ & $34 / 32$ & $266 / 227$ & $527 / 465$ \\
Apparent $\mathrm{p} K_{\mathrm{a}}$ & $6.21 / 6.57$ & $5.96 / 6.26$ & $5.86 / 6.16$
\end{tabular}

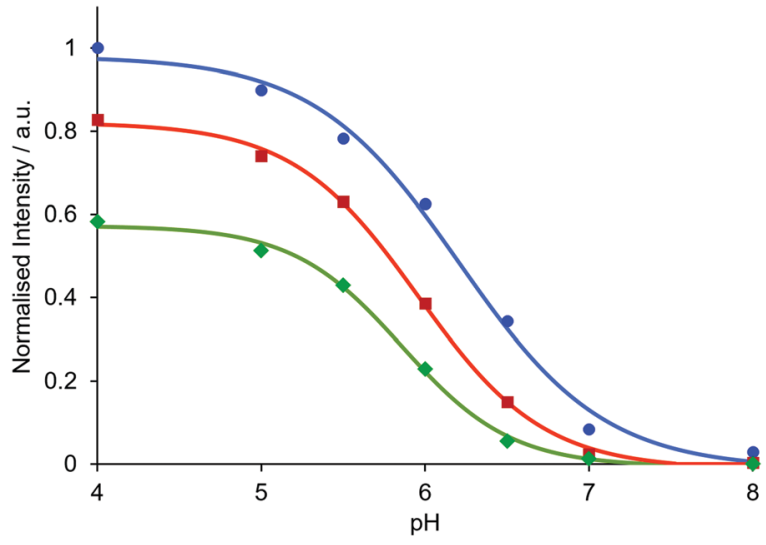

Fig. 3 Relative emission intensity of EuL ${ }^{1 b}\left(\lambda_{\mathrm{em}} 613 \mathrm{~nm}\right)$ as a function of $\mathrm{pH}$ for different time periods of signal acquisition (blue $=60-460 \mu \mathrm{s}$, red $=$ $1000-2000 \mu \mathrm{s}$, green $=1500-2500 \mu \mathrm{s}$ ). Data are normalised to a $60-460$ $\mu$ s time window at $\mathrm{pH} 4$. Measurements were made in aqueous solutions of $\mathrm{NH}_{4} \mathrm{OAc}(\mathrm{pH} 4$ and 5), MES ( $\mathrm{pH} 5.5,6,6.5), \mathrm{HEPES}(\mathrm{pH} 7)$ and $\mathrm{NH}_{4} \mathrm{HCO}_{3}$ ( $\mathrm{pH}$ 8) buffers ( $c=20 \mu \mathrm{M}, 0.1 \mathrm{M}$ buffer in $0.1 \mathrm{M} \mathrm{NaCl}$ ).

transfected HEK-293 cells is negligible under the same conditions, this demonstrates that labelling of the GLP-1R with $\mathbf{E u L}{ }^{2 c}$ on the cell surface is specific, and the compound does not accumulate in endosomal particles, as this would give rise to an

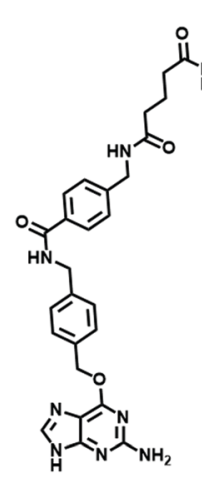

A

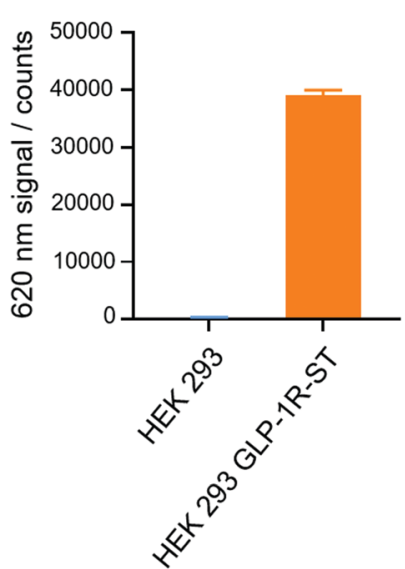

B

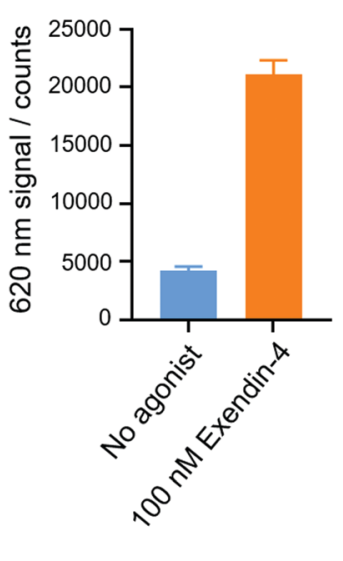

Fig. 4 Time gated measurements of the Eu $\Delta J=2$ band intensity of: (A) GLP-1R-ST receptor labelling, using EuL ${ }^{2 c}(200 \mathrm{nM})$ on non-transfected and GLP-1R-ST expressing HEK293 cells; (B) GLP-1R-ST receptor internalisation, $1 \mathrm{~h}$ after addition of $100 \mathrm{nM}$ of the peptide agonist, Exendin-4, versus a control with no agonist added (see ESI $\dagger$ for experimental details). 
observable luminescence signal. As has been shown for related Eu complexes, ${ }^{12}$ the introduction of peripheral anionic sulfonate groups in the probe structure suppresses any non-specific labelling to cells.

To follow receptor internalisation by monitoring endosomal acidification, $100 \mathrm{nM}$ of the GLP-1R peptide agonist Exendin-4 was added to the $\mathbf{E} \mathbf{u} L^{2 c}$ labelled receptors at $\mathrm{pH}$ 7.4. Measuring the time gated luminescence at $620 \mathrm{~nm}$ after a $1 \mathrm{~h}$ incubation revealed a 5 -fold increase in luminescence intensity, as a result of both receptor internalisation and the subsequent endosomal acidification (Fig. 4B). Further pharmacological studies are underway on GLP-1R and other membrane receptors to reveal whether these promising europium $\mathrm{pH}$ probes have a bright future for studying receptor internalisation and its time dependence, both in vitro and in live cell assays.

We thank EPSRC (EP/L01212X/1) for grant and partial studentship support (JDF).

\section{Conflicts of interest}

Authors state that there are no conflicts to declare.

\section{Notes and references}

1 M. Kaksonen and A. Roux, Nat. Rev. Mol. Cell Biol., 2018, 19, 313-326.

2 Y. Urano, D. Asanuma, Y. Hama, Y. Koyama, T. Barrett, M. Kamiya, T. Nagano, T. Watanabe, A. Hasegawa, P. L. Choyke and H. Kobayashi, Nat. Med., 2009, 15, 104-109.

3 D. Asanuma, Y. Takaoka, S. Namiki, K. Takikawa, M. Kamiya, T. Nagano, Y. Urano and K. Hirose, Angew. Chem., Int. Ed., 2014, 53, 6085-6089.

4 A. Grover, B. F. Schmidt, R. D. Salter, S. C. Watkins, A. S. Waggoner and M. P. Bruchez, Angew. Chem., Int. Ed., 2012, 51, 4838-4842.

5 M. Isa, D. Asanuma, S. Namiki, K. Kumagai, H. Kojima, T. Okabe, T. Nagano and K. Hirose, ACS Chem. Biol., 2014, 9, 2237-2241.
6 M. Starck, J. D. Fradgley, R. Pal, J. M. Zwier, L. Lamarque and D. Parker, Chem. - Eur. J., 2021, 27, 766-777.

7 M. Soulié, F. Latzko, E. Bourrier, V. Placide, S. J. Butler, R. Pal, J. W. Walton, P. L. Baldeck, B. Le Guennic, C. Andraud, J. M. Zwier, L. Lamarque, D. Parker and O. Maury, Chem. - Eur. J., 2014, 20, 8636-8646.

8 S. J. Butler, M. Delbianco, L. Lamarque, B. K. McMahon, E. R. Neil, R. Pal, D. Parker, J. W. Walton and J. M. Zwier, Dalton Trans., 2015, 44, 4791-4803.

9 M. Starck, R. Pal and D. Parker, Chem. - Eur. J., 2016, 22, 570-580.

10 S. J. Butler, L. Lamarque, R. Pal and D. Parker, Chem. Sci., 2014, 5, 1750-1756.

11 S. Shuvaev, M. Starck and D. Parker, Chem. - Eur. J., 2017, 23, 9974-9989.

12 M. Delbianco, V. Sadovnikova, E. Bourrier, G. Mathis, L. Lamarque, J. M. Zwier and D. Parker, Angew. Chem., Int. Ed., 2014, 53, 10718-10722.

13 M. Starck, J. D. Fradgley, S. Di Vita, J. A. Mosely, R. Pal and D. Parker, Bioconjugate Chem., 2020, 31, 229-240.

14 J. W. Walton, R. Carr, N. H. Evans, A. M. Funk, A. M. Kenwright, D. Parker, D. S. Yufit, M. Botta, S. De Pinto and K.-L. Wong, Inorg. Chem., 2012, 51, 8042-8056.

15 A. Keppler, S. Gendreizig, T. Gronemeyer, H. Pick, H. Vogel and K. Johnsson, Nat. Biotechnol., 2003, 21, 86-89.

16 J. M. Zwier, H. Bazin, L. Lamarque and G. Mathis, Inorg. Chem., 2014, 53, 1854-1866.

17 J. M. Zwier, T. Roux, M. Cottet, T. Durroux, S. Douzon, S. Bdioui, N. Gregor, E. Bourrier, N. Oueslati, L. Nicolas, N. Tinel, C. Boisseau, P. Yverneau, F. Charrier-Savournin, M. Fink and E. Trinquet, J. Biomol. Screen., 2010, 15, 1248-1259.

18 J. Xu, T. M. Corneillie, E. G. Moore, G.-L. Law, N. G. Butlin and K. N. Raymond, J. Am. Chem. Soc., 2011, 133, 19900-19910.

19 (a) D. Donnelly, Br. J. Pharmacol., 2012, 166, 27-41; (b) S. N. Roed, P. Wismann, C. R. Underwood, N. Kulahin, H. Iversenn, K. A. Cappelen, L. Schäffer, J. Lehtonen, J. Hecksher-Soerensen, A. Secher, J. M. Mathiesen, H. Bräuner-Osborne, J. L. Whistler, S. M. Knudsen and M. Waldhoer, Mol. Cell. Endocrinol., 2014, 382, 938-949.

20 W. J. C. van der Velden, F. X. Smit, C. B. Christiansen, T. C. Møller, G. M. Hjortø, O. Larsen, S. P. Schiellerup, H. Bräuner-Osborne, J. J. Holst, B. Hartmann, T. M. Frimurer and M. M. Rosenkilde, ACS Pharmacol. Transl. Sci., 2021, 4, 296-313. 